\title{
An evaluation of fibrous structure and physical characteristics of Cutia nut (Couepia edulis Prance) shell
}

\author{
Odílio Benedito Garrido ASSIS ${ }^{1}$, José Dalton Cruz PESSOA²
}

\section{ABSTRACT}

The Cutia-nut (Couepia edulis Prance), a species originally from the Amazon region, has a kernel with reasonable nutritional value and a hard and thick woody shell that constitute most of the fruit. After the kernel removal, the shells are regarded as waste. The possibility of using such shells, as raw material for burning or charcoal production, as well as milled residue for structural reinforcement materials is quite feasible, considering environmental and economical aspects. There is, however, a complete lack of characterization of the Cutia-nut shell and other similar species which can aggregate desirable qualities for application as engineering material. In this study some analyses are presented aiming at providing information for potential uses of these residues. In general, the shells follow a regular shape with certain dimensional proportionality to the kernel. The shell is a fibrous material with high lignin content, present low water absorption and high resistance to natural degradation.

KEYWORDS: Cutia-nut, shell characterization, fibrous structure, natural waste utilization

\section{Uma avaliação da estrutura fibrosa e das características físicas da casca da Castanha de cutia (Couepia edulis Prance)}

\begin{abstract}
RESUMO
A castanha-de-cutia (Couepia edulis Prance), uma espécie típica da regiáo amazônica, é possuidora de uma amêndoa de razoável valor nutricional e caracterizada por ter uma casca espessa e altamente resistente, que constitui a maior parte do fruto. Esta casca, após a retirada da amêndoa, é totalmente descartada. A possibilidade do aproveitamento das cascas, seja como matéria prima para a queima ou simples confecção de carvão, ou como elemento para uso como aditivo de reforço em materiais estruturais é plenamente viável, não somente do ponto de vista ambiental mas também econômico. Há, contudo, uma ausência total de caracterizaçóes da casca da castanha-de-Cutia e de demais espécies tropicais similares que potencialmente podem agregar qualidades desejadas para aplicaçôes como materiais de engenharia. Neste trabalho são apresentadas algumas análises realizadas que podem vir a subsidiar o potencial emprego desses resíduos. De um modo geral, as cascas apresentam formatos regulares com certa proporcionalidade dimensional com a amêndoa. São fibrosas e com alto teor de lignina o que garante baixa absorção de água e alta resistência à degradação natural.
\end{abstract}

PALAVRAS-CHAVE: Castanha de Cutia, caracterização da casca, estrutura fibrosa, usos de resíduos naturais

${ }^{1}$ Embrapa Instrumentação Agropecuária - Rua XV de Novembro, 1452, C.P. 741, CEP: 13560-970 - São Carlos S.P., Brazil. E-mail: odilio@cnpdia.embrapa.br

2 Empresa Brasileira de Pesquisa Agropecuária - EMBRAPA 


\section{INTRODUCTION}

The Cutia-nut (Couepia edulis Prance) is a native Brazilian fruit originally from the western Amazon rainforest. The Cutia-nut develops in large trees (20-35 m in height) rarely cultivated, which bears fruits from November to May. The nuts are highly appreciated by rodents that are able to cut off their tough shell. The kernel is tasteful, oily and rich in proteins, though poor in water and azote (Yuyama et al.,1996). The crude oil can be extracted by mechanical pressing and use for cooking. The oil is odorless, naturally light, and presents high levels of monounsaturated fats and antioxidants conferring a long and stable shelf life.

The precocity of fruit production is one of great advantage. As observed by Quadros (2003), the tree bears fruits in six or seven years, which is considerably fast compared to other edible nuts. Nevertheless, the kernel and its subproducts are not exploited commercially (Ferreira et al.,1987).

The harvest of Cutia-nut is quite primitive. Fallen nuts are manually collected and stored in a dry and ventilated place. Among inhabitants of the region, the kernel is usually eaten toasted and grounded together with manioc flour. Because of its organoleptics qualities, however, it also can be consumed raw.

The Cutia-nut fruit has a drupe, ellipsoidal shape, consisting of a thick external brown husk, with a very hard fibrous structured shell inclosing the kernel. The average fruit weighs approximately $82 \mathrm{~g}$ and the kernel not more than $15 \mathrm{~g}$ (Souza et al.,1996). The extraction of the kernel from the shell has been a manual operation. The nuts are immersed in water for about an hour for softening and then cracked, either manually or mechanically, using a wooden mallet or a hammer. Recently, the Embrapa Instrumentação Agropecuária, at São Carlos, SP, has developed a rotating cutting device for almond extraction, designed for field and small-scale industrial applications, which was adapted for Cutia-nut processing (Pessoa \& van Leeuwen, 2006).

In the present study the constitution and structural aspects of the Cutia-nut shell, which consist the major fraction of the fruit and are totally regarded as waste, are characterized aiming at the identification of potential uses for this residue.

\section{MATERIAL AND METHODS}

Cutia-nut fruit samples were provided by Embrapa Amazônia Oriental (Belém, PA). All fruits were collected in one specific region and in a same season. The shells were manually removed from the fruit, using a U-shaped blade. Digital images of longitudinal and transversal cut shell surfaces were recorded. The husk formats were statistical evaluated in terms of sphericity and axis length by using image analysis software (Image Tool For Windows v.3.0). Around 30 fruits were randomly observed.

Density was measured through geometrical approximation in cylindrical samples $(1.5 \times 1.0 \mathrm{~cm})$ removed from different regions of the shell. Water absorption was estimated by means of mass uptake as a function of time, in intact fruits immersed in tap water at room temperature. Before and after soaking, the specimens were weighed and the percent weight gain $(P W G)$ calculated as:, where: $W_{o}=$ initial weight and $W_{f}=$ final weight of the sample. Optical and electron scanning microscopy (Philips XL 30) was also used for fibers structure observation.

Chemical characterization included dry matter (DM), crude protein $(\mathrm{CP})$, acid detergent fiber (ADF) and neutral detergent fiber (NDF). The contents were determined using the Kjeldhal wet method (Nelson \& Sommer,1973; Hall et al.,1997), for crushed and sieved ( $<2 \mathrm{~mm}$ ) shell fractions of $0.35 \mathrm{~g}$ dissolved into $35 \mathrm{ml}$ of reagents (analytical grade). The apparent lignin content was evaluated according to Bruce and West (1989) wet-lab chemical method. All analyses were carried out in duplicate.

\section{RESULTS AND DISCUSSION}

Figure 1 presents the external aspect of the Cutia-nut and the correspondent sections of the cut shell. The shell is basically composed of lignincellulose and hemicelluloses structures with a smooth surfaced epicarp and a thick and woody mesocarp. The fibers are oriented predominantly in longitudinal direction. In Figure 2 details of external shell surface and internal fibers distribution are presented.

Through image analysis software, the shapes were approximated by polygons (convex hull), allowing a quantification of the total projected area in each cut section. Such analysis aimed to collect information about size relationship between fruit and kernel. From longitudinal sections measurements, the kernel occupies nearly $45 \%$ of the total area and on transversal sections the proportional area correspondent to the kernel is $35 \%$. Statistically, one may say that the shell accounts for around $60 \%$ of total fruit volume. Discrete results can be adjusted through a linear relationship as plots in Figure 3(a,b), suggesting that the larger the fruit shell the larger the kernel inside.

Quantitative data extracted from images include the fruit sphericity. The sphericity (also named as circularity in twodimensions) is a compound symmetry, which indicates the degree to which a section approaches the shape of a "sphere". The sphericity index is obtained using a relation between the maximum inscribing circumference radius to the minimum circumscribing circumference radius as $\varepsilon=\mathrm{R}_{i} / \mathrm{R}_{i} \cdot \varepsilon$ is a non-dimensional number between $0<\varepsilon \leq 1$, where 1 is a 

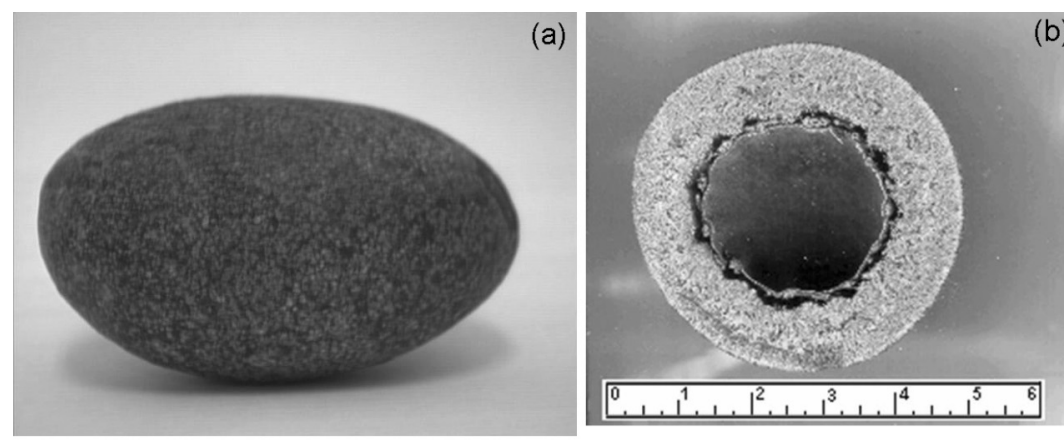

(b)

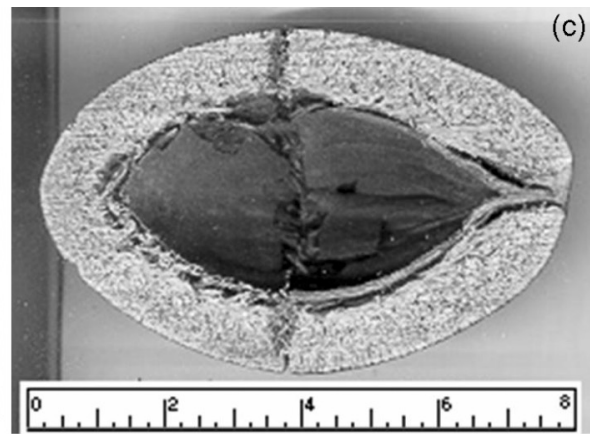

Figure 1 - (a) Cutia-nut fruit, external apparence; (b) Transversal section, where the secondary axis length, approximatelly, 5cm; (c) Longitudinal section, with major axis of around 8cm (Pessoa et al., 2004).
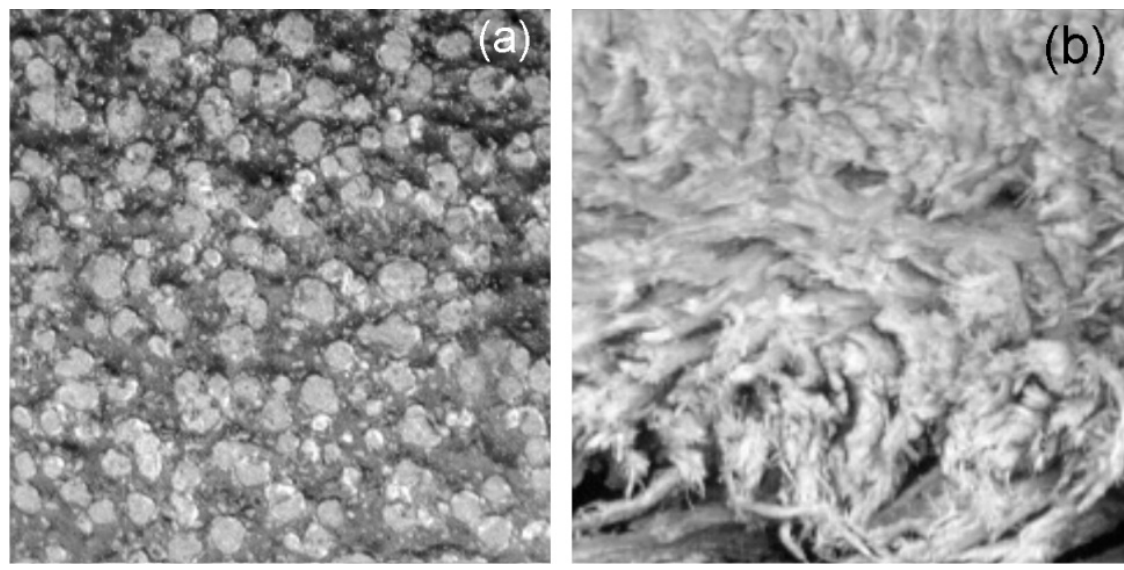

Figure 2 - (a) Shell surface texture aspect and (b) Fiber aspects in perpendicular cross-section (5X amplification).

perfect circle. For the analyzed lot, the sphericity was found to be size dependent, with an average value of $\varepsilon=0.36 \pm 0.12$ in an exponential relationship to fruit perimeter, as plotted in Figure 4. The results evidence that the larger the fruit the greater is the tendency toward being oblong in shape. Since the kernel follows the shell, the format of the fruit will determine the kernel shape.

The external geometrical characteristics of the Cutia-nut plays a fundamental role in projecting mechanical devices for almond extraction, such as the rotating cutting system in development by Pessoa \& van Leeuwen (2006).

The density measured in cylindrical samples extracted from several fruits and at different positions in the shell resulted in quite similar values. Few deviations were found in function of position, indicating a very homogenous shell structure. The average density was $0.688 \pm 0.057 \mathrm{gcm}^{-3}$ close to values of eucalyptus wood as measured by Wimmer et al., (2002) and by Macedo et al., (2002). Concerning water absorption, the resultant gain of mass as a function of time is presented in Figure 5. A logarithmic behavior is observed with an initial fast hydration with apparent saturation at around 10 hours. The numerical values of mass gain are relatively low considering fruit characteristics. As matter of comparison, in other natural fiber-based materials, such as coconut coir and sisal, the water absorption ranges 93 and $400 \%$ in weight, respectively (Savastano and Devito, 1998). Furthermore, in the Cutia-nut fruit the uptake takes place essentially by water infiltration through shell cracks, ordinarily found in the peduncle cavity region, rather than by skin absorption. The resistance to water is confirmed by the imperceptible shell swelling after 24 hour immersion.

Scanning electron microscopy reveals the composite structure of the shell walls. As can be seen in Figure 6(a) the cellulose microfibrils are glued together by the middle lamellas. The matrix is very dense with fibers tailored isometrically, regarding orientation and size. Such physical features confer high mechanical strength and a low affinity towards water. In cross-section image (Figure 6(b)) the fibers are uniformly oriented and have thickness not superior to $3.0 \mu \mathrm{m}$.

Table 1 summarizes the compositional analysis of the parts. The resulting data shows that the Cutia-nut is composed essentially of dry matter, i.e., highly fibrous material with very low protein content, considering the whole of the fruit. The shell presents approximately $97 \%$ of insoluble fibers in neutral 

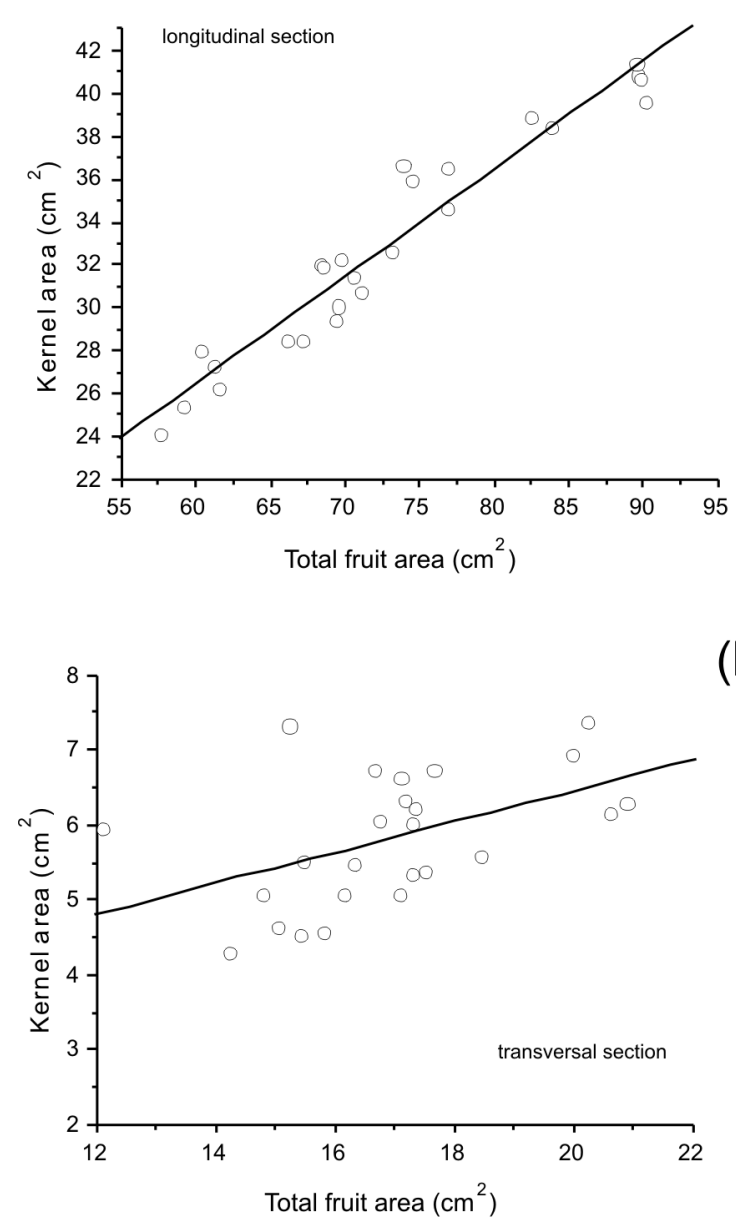

(b)

Figure 3 - Kernel and total fruit area relation in: (a) Longitudinal section: Kernel area $=0.50 *$ Total area $-3(\mathrm{r} 2=0.933)$; (b) Area relation in transversal section: Kernel area $=0.20$ * Total area $+2(\mathrm{r} 2=0.2346)$

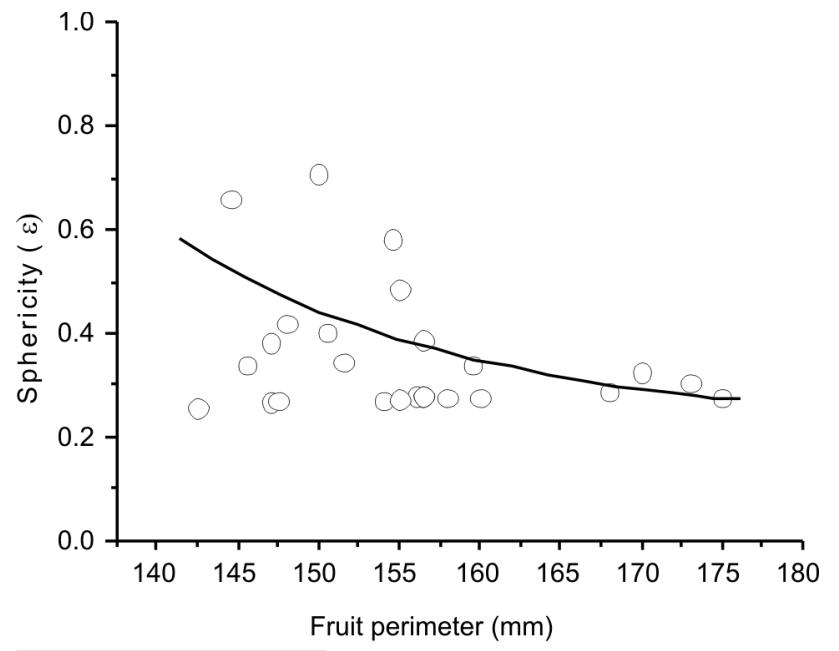

Figure 4 - Sphericity index in function of fruit perimeter. (a)

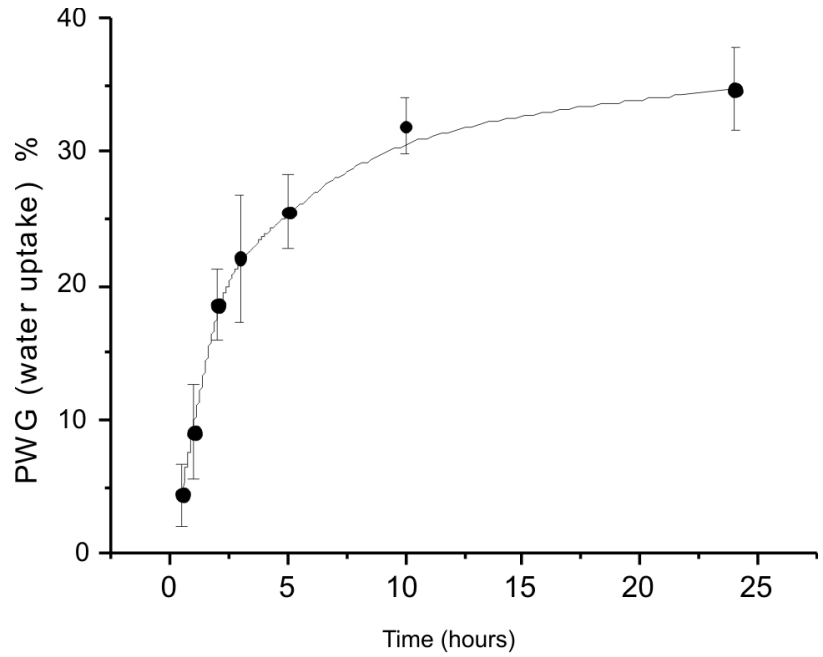

Figure 5 - Percentage of mass acquisition as function of immersion time in water for the whole fruit.
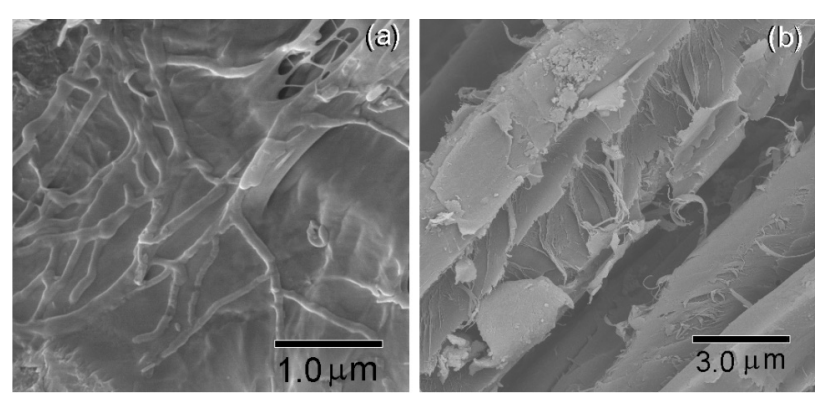

Figure 6 - Scanning electron microscopy of shell cross-section: (a) Microfibres distributions in lignocellusic structure; (b) Details of fibers on cut surface.

medium, while the amount of fiber in kernel is less than $28 \%$ of the total fruit. The analysis in acid reagent indicates easy dissolution of the fiber in the kernel when compared to tests conducted in neutral media.

Table 1 - Summary of analytical percentage determination.

\begin{tabular}{lcccc}
\hline Position & \% DM & \% CP (DM) & \% NDF (DM) & \% ADF (DM) \\
\hline Shell & 92.10 & 2.1 & 95.67 & 84.79 \\
Kernel & 96.86 & 10.9 & 27.67 & 73.92 \\
\hline
\end{tabular}

$\mathrm{DM}=$ dry matter, $\mathrm{CP}=$ crude protein (Kjeldhal method), NDF = neutral detergent fiber and $A D F=$ acid detergent fiber.

Since crude protein is essentially located in the kernel and the shell consists of a great amount of insoluble fibers with no nutritional value, the results suggested that the disposed shells might represent an interesting raw material for industrial purposes.

The measured lignin content was found to be relatively high (average of $30.47 \%$ ) similar to values reported to corn stalks and coir (Hon, 2000). Wood structures with high 
lignin are especially strong in compression. It is also well known that the higher the proportion of lignin the lower the bioavailability of the substrate. Since lignin is almost totally insoluble in most solvents, the degradability of the molecules is particularly hard and their spatial distribution acts as a net that contributes to reducing the area available to enzymatic penetration (Van Soest, 1994). Such characteristics explain the very resistant features of Cutia-nut shell. The shell composition associated with the low swelling capability makes it difficult to a chemical pulp and, in some sense, reduce its viability to be used as raw material for pulp and paper manufacturing. The shell has, however, all the physic-chemical characteristics necessary for yielding high quality charcoal via carbonization process (Demirbas, 2001).

One alternative to a more consistent use of Cutia-nut shells is in crushed condition as an aggregate in building materials. The application of very low-value agricultural waste as granular additive in civil construction and engineering materials is a worldwide trend, not only in function of economical interests but also due to growing concern about environmental aspects. The use of locally available raw materials such as sisal, banana, coconut and eucalyptus in fiber-reinforced composites and in lightweight concretes, for example, has been the subject of continuous evaluation (Savastano et al., 2000; Agopyan et al., 2005; Coutts, 2005).

The application of powdered shell material as reinforcement component is also suitable for use in furnishing industries. Fragmented fiber structures can be thermoplastically pressed into boards (Bentrup \& Dittmar, 2006), for furniture parts or to be used as roofing material, water reservoirs, external and internal partitioning boards among others.

The preliminary results suggest that the Cutia-nut shell could be a potential engineering material. Additional evaluations, however, are necessary to provide a more comprehensive framework for delineating possible and worthwhile applications.

\section{ACKNOWLEDGMENTS}

The authors would like to thank CNPq, Embrapa Instrumentação Agropecuária for instrumental support, and Embrapa Amazônia Oriental for proving the nut samples used in this characterization.

\section{LITERATURE CITED}

Agopyan, V.; Savastano Jr, H.; John, V.M.; Cincotto, M.A. 2005. Developments on vegetable fibre-cement based materials in São Paulo, Brazil: an overview. Cement \& Concrete Composites, 27: $527-536$
Bentrup, K-L.; Dittmar, H. 2006. Method of producing a thermoplastically moldable fiber-reinforced semifinished product. US Patent. N. 2006/0244170 A1.

Bruce, R.J.; West, C.A. 1989. Elicitation of lignin biosynthesis and isoperoxidase activity by pectic fragments in suspension culture of castor bean. Plant Physiology, 91: 889-897.

Coutts, R.S.P. 2005. A review of Australian research into natural fibre cement composites. Cement \& Concrete Composites, 27: $518-526$.

Demirbas, A. 2001. Biomass to charcoal, liquid, and gaseous products via carbonization process. Energy Sources, 23: 579-587.

Ferreira, F.R.; Ferreira, S.A.N.; Carvalho, J.E.U. 1987. Espécies frutíferas pouco exploradas, com potencial econômico e social para o Brasil. Revista Brasileira de Fruticultura, 9:11-22.

Hall, M.B.; Lewis, B.A.; Van Soest, P.J.; Chase, L.E. 1997. A simple method for estimation of neutral detergent-soluble fibre. Journal of the Science of Food and Agriculture, 74:441-449.

Hon, D. N. S. 2000. Pragmatic approaches to utilization of natural polymers: Challenges and opportunities. In: Frollini, E.; Leão, A.; Mattoso, L.H.C. (Eds). Natural Polymers and Agrofibers Composites. Embrapa Instrumentação Agropecuária, São Carlos, São Paulo. p.1-14.

Macedo, A.; Vaz, C.M.P.; Pereira, J.C.D.; Naime, J.M.; Cruvinel, P.E.; Crestana, S. 2002. Wood density determination by X-and gamma-ray tomography. Holzforschung, 56(5): 535-540.

Nelson, D.W.; Sommer, L.E. 1973. Determination of total nitrogen in plant material.Agronomy Journal, 65:109-112.

Pessoa, J.D.C.; Assis, O.B.G.; Braz, D.C. 2004. Caracterização morfomecânica para beneficiamento do fruto da Castanha-deCotia (Couepia edulis Prance). Revista Brasileira de Fruticultura, 26(1):103-106.

Pessoa, J.D.C.; Van Leeuwen, J. 2006. Development of a shelling method to recover whole kernels of the cutia nut (Couepia edulis). Revista Brasileira de Fruticultura, 28(2): 236-239.

Quadros, M. 2003. Frutas emergentes. Revista Agroamazonia. n.10, (disponível em: http://www.revistaagroamazonia.com.br). Acesso: (12/04/2005).

Savastano Jr., H.; Devito, R.A. 1998. Fiber cement based composites for civil construction. In: $2^{\text {nd }}$ International Symposium on Natural Polymers and Composites. (ISNaPol'98) São Pedro, São Paulo. Proceedings, p.119-121.

Savastano Jr., H.; Warden, P.G.; Coutts, R.S.P. 2000. Brazilian waste fibre as reinforcement for cement based composites. Cement \& Concrete Composites, 22(5): 379-384.

Sousa, A.G.C.; Sousa, N.R.; Silva, M.E.L.; Nunes, C.D.M.; Canto, A. C; Cruz, L.A.A. 1996. Fruteiras da Amazônia. Brasília: EMBRAPA-SPI/Manaus: EMBRAPA-CPAA, 204pp.

Van Soest, P.J. 1994. The Nutritional Ecology of the Ruminant. $2^{\text {nd }}$ edition.; Cornell University Press, Ithaca, NY, USA. 476 pp. 
Wimmer, R.; Downes, G.M.; Evans, R. 2002. High-resolution analysis of radial growth and wood density in Eucalyptus nitens, grown under different irrigation regimes. Annales of Forest Science, 59:519-524.

Yuyama, K.L.O.; Aguiar, J.P.L.; Macedo, S.H.M.; Gioia, T.; Yuyama, K. 1996. Perfil nutricional da castanha de cutia (Conepia edulis) e castanha de galinha (Couepia longipendula). In: Congresso Brasileiro de Ciência e Tecnologia de Alimentos. INAN. Manaus, Amazonas, p. 37.

Recebido em 29/11/2007

Aceito em 06/08/2009 